\title{
Ecosystem engineering and biodiversity in coastal sediments: posing hypotheses
}

\author{
Tjeerd J. Bouma $\cdot$ Sergej Olenin $\cdot$ Karsten Reise $\cdot$ \\ Tom Ysebaert
}

Received: 21 December 2008 / Revised: 15 January 2009 / Accepted: 17 January 2009 / Published online: 12 February 2009

(C) The Author(s) 2009. This article is published with open access at Springerlink.com

\begin{abstract}
Coastal sediments in sheltered temperate locations are strongly modified by ecosystem engineering species such as marsh plants, seagrass, and algae as well as by epibenthic and endobenthic invertebrates. These ecosystem engineers are shaping the coastal sea and landscape, control particulate and dissolved material fluxes between the land and sea, and between the benthos and the passing water or air. Above all, habitat engineering exerts facilitating and inhibiting effects on biodiversity. Despite a strongly growing interest in the functional role of ecosystem engineering over the recent years, compared to food web analyses, the conceptual understanding of engineering-mediated species interactions is still in its infancy. In the present paper, we provide a concise overview on current insights and propose two hypotheses on the general mechanisms by which
\end{abstract}

Communicated by K. Reise.

T. J. Bouma $(\bowtie) \cdot$ T. Ysebaert

Centre for Estuarine and Marine Ecology,

Netherlands Institute of Ecology (NIOO-KNAW),

Yerseke, The Netherlands

e-mail: t.bouma@nioo.knaw.nl

T. Ysebaert

Wageningen IMARES,

Institute for Marine Resources and Ecosystem Studies,

Yerseke, The Netherlands

S. Olenin

Unifob Environmental Research, Bergen, Norway

S. Olenin

Coastal Research and Planning Institute, Klaipeda University,

Klaipeda, Lithuania

K. Reise

Alfred Wegener Institute for Polar and Marine Research,

Wadden Sea Station Sylt, List, Germany ecosystem engineering may affect biodiversity in coastal sediments. We hypothesise that autogenic and allogenic ecosystem engineers have inverse effects on epibenthic and endobenthic biodiversity in coastal sediments. The primarily autogenic structures of the epibenthos achieve high diversity at the expense of endobenthos, whilst allogenic sediment reworking by infauna may facilitate other infauna and inhibits epibenthos. On a larger scale, these antagonistic processes generate patchiness and habitat diversity. Due to such interaction, anthropogenic influences can strongly modify the engineering community by removing autogenic ecosystem engineers through coastal engineering or bottom trawling. Another source of anthropogenic influences comes from introducing invasive engineers, from which the impact is often hard to predict. We hypothesise that the local biodiversity effects of invasive ecosystem engineers will depend on the engineering strength of the invasive species, with engineering strength defined as the number of habitats it can invade and the extent of modification. At a larger scale of an entire shore, biodiversity need not be decreased by invasive engineers and may even increase. On a global scale, invasive engineers may cause shore biota to converge, especially visually due to the presence of epibenthic structures.

Keywords Ecosystem engineering - Biodiversity · Invasive species - Bioturbation · Endobenthos · Epibenthos · Introduced species · Soft bottom · Facilitation · Inhibition $\cdot$ Species interactions

\section{Introduction}

Understanding biodiversity, for a long time, has been recognised as a highly important issue in ecological research which continues to receive a lot of attention 
(e.g. $>150$ publications in Nature and Science over the last 3 years; ISI web of knowledge). One important aspect of these studies is aimed at unravelling the role of single species that are capable to mediate the environment for the entire biological community. Already, at the dawning of modern ecology, the term "Edificator" (Latin: aedificatorconstructor, builder) was introduced to indicate a plant species which plays the crucial role in structuring the environment and providing niches for associated and dependant organisms (Braun-Blanquet 1928). Originating in Pflanzensoziologie (phytocenology or plant ecology), this concept was widened to include also "edificating" animal species and in 1930s-1950s it was also applied in hydrobiological studies (Reimers and Yablokov 1982), mainly in German and Russian literature. This term is closely related to the more recently introduced concept of ecosystem engineers, which is used to describe organisms causing a biologically mediated habitat modification (Jones et al. 1994). In recent years, the notion of ecosystem engineers has been recognised as a highly relevant concept (with over 840 citations to date), with large consequences for neighbouring organisms and local biodiversity in a broad range of ecosystems (e.g. see Bruno et al. 2003; Crooks 2002; Wright and Jones 2006; Wright et al. 2006). Jones et al. (1994, 1997) distinguished two types of ecosystem engineering. In autogenic engineering, the organisms change the environment via their own physical structures and are thus part of the engineered habitat (e.g. trees in a forest), whereas in allogenic engineering, organisms transform living or non-living materials from one physical state to another (e.g. dam creation by beavers).

Ecosystem engineers tend to be most dominant in stressful environments (Jones et al. 1997) and consequently, autogenic and allogenic ecosystem engineers can have a striking presence in many coastal sediments (Fig. 1). Benthic ecosystem engineers inhabiting coastal sediments can cause a multitude of biogenic habitat transformations such as sediment stabilisation and destabilisation or bioconstructions and bioturbations (Reise 2002; Widdows and Brisley 2002). In general, benthic engineers can be divided into epibenthic and endobenthic organisms depending on whether they spend most of their lifetime above or below the sediment, respectively. Many endobenthic macroinvertebrate species modify the sedimentary habitat through their activities and can be considered allogenic ecosystem engineers. Endobenthic bottom dwelling species affects a number of resource flows mainly through bioturbation and bioirrigation (Rhoads 1974; Cadée 2001; Reise 2002). Bioturbation is a biological mixing process that alters both the physical structure and the biogeochemical nature of the sediment, by increasing exchange fluxes at the sedimentwater interface. Bioirrigation is the active flushing of burrows (and its surrounding sediment) with overlying waters, thereby enhancing the exchange rates between sediment and water column. The combination of bioturbation and bioirrigation can strongly shape the environment and strongly affect ecosystem functioning (Meysman et al. 2006). Well-known examples of endobenthic ecosystem engineers are, e.g., lugworms Arenicola marina (Volkenborn et al. 2007a; Fig. 1), burrowing ghost shrimps Callianassa sp. (Atkinson and Taylor 2005) and mangrove crabs such as burrowing sesarmid (Grapsidae) and fiddler crabs (Ocypodidae) (Kristensen 2008). The most dominant epibenthic ecosystem engineers inhabiting temperate coastal sediments are reef building filter feeders or dense vegetations of seagrasses, macroalgae or salt marsh species (Fig. 1). By their epibenthic structure, these organisms affect local hydrodynamics (e.g. for vegetations, see Ackerman and Okubo 1993; Bouma et al. 2005; Koch and Gust 1999; Koch et al. 2006; Peterson et al. 2004; Peralta et al. 2008, and references therein; for reef building filter feeders, see Fréchette and Bourget 1985; Widdows et al. 1998, 2002), and thereby often affect local sediment dynamics and particle trapping (e.g. for vegetations, see Koch 2001; Gacia et al. 2003; Castellanos et al. 1994; Hemminga et al. 1998; van Hulzen et al. 2007; for reef building filter feeders, see Widdows et al. 1998, 2002). These epibenthic ecosystem engineers thus modify the sedimentary habitat mainly through their physical structures, and thus are true autogenic ecosystem engineers.

Understanding the biodiversity effects of the multitude of biogenic habitat transformations by ecosystem engineers inhabiting coastal sediments is rather complex. Within the European network of excellence MarBEF, we have tried to enhance our general understanding of the biodiversity effect of ecosystem engineers in soft-sediment coastal ecosystems by establishing collaboration between related research groups. During our meetings, we have formulated two conceptual hypotheses which are presented here and may stimulate further discussions and testing.

\section{Habitat creation by ecosystem engineers: effects of thresholds and positive feedback loops}

Other than trophic relations where intraspecific competition for space, nutrients or prey constitutes a negative feedback mechanism on population density, habitat modifications by ecosystem engineers tend to constitute a positive feedback on conspecifics (Cuddington and Hastings 2004). These positive feedbacks generally require a minimal threshold to be surpassed before becoming effective (e.g. Bouma et al. 2009; van der Heide et al. 2007). As a result, at sediment shores, isolated individuals of autogenic engineers often come and go. However, once several individuals managed to establish, they synergistically succeed in modifying the 
Fig. 1 Visual example of the major habitat modifying impact that can be exerted by a bioturbating endobenthic allogenic ecosystem engineer (a) and a sediment stabilising epibenthic autogenic ecosystem engineer (b). The smooth sediment surface on the mudflat was formed upon the exclusion of bioturbating lugworms (Arenicola mari$n a$ ) by burying a net in the sediment (a; picture courtesy of Nils Volkernborn). The presence of the cordgrass Spartina angli$c a$ causes the formation of a dome shaped tussock (b)
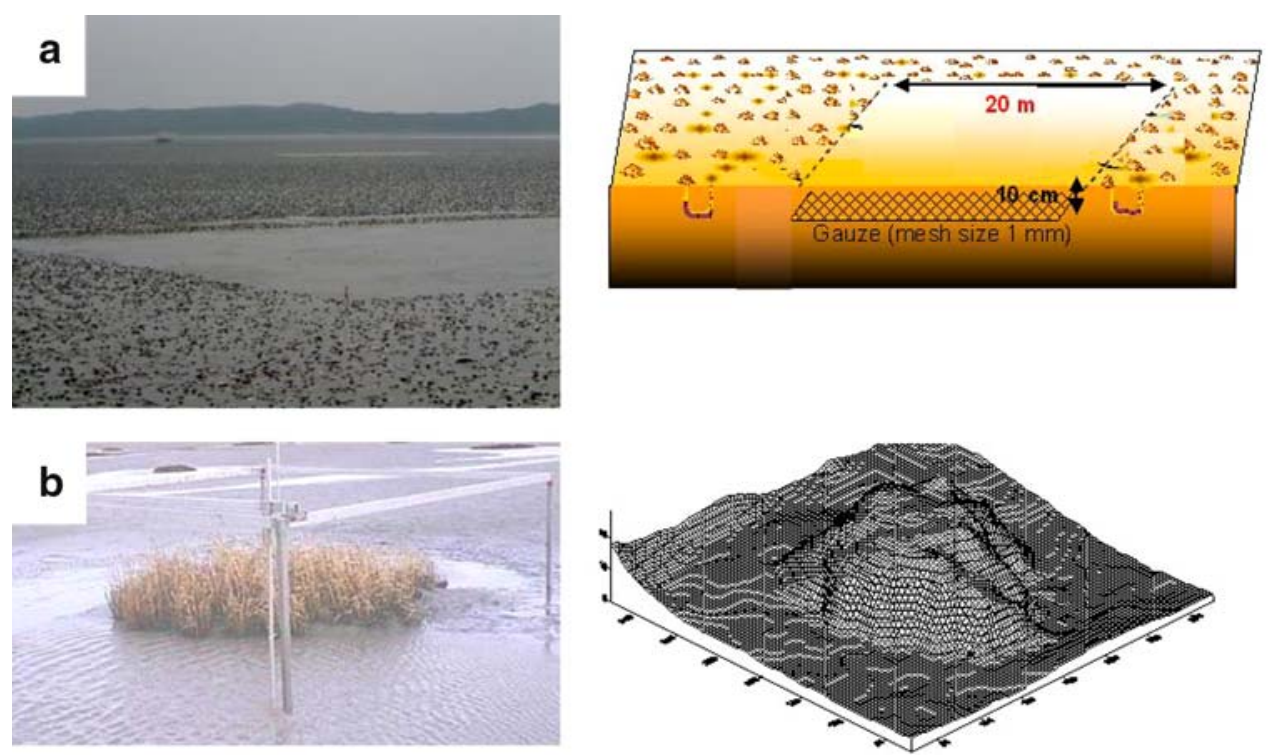

environment to their own advantage, and patches of marsh plants, meadows of seagrass or beds of suspension feeders are known to persist over long periods of time (e.g. van Wesenbeeck et al. 2008). The same kind of positive feedback mechanisms and thresholds appear to apply to allogenic ecosystem engineers. For example, for lugworms, it has been suggested that their bioturbating activities contribute to the maintenance of their sandy habitat by preventing a succession towards muddy bottoms (Volkenborn et al. 2007a). However, again thresholds apply as juvenile lugworms first have to settle outside the areas that are strongly bioturbated by the adults and only later in life fill in gaps among the adults (Reise et al. 2001). In stressful environments, such as the seashore, the combination of thresholds and positive feedback dynamics may induce alternative stable state dynamics (e.g. van der Heide et al. 2007). This typically results in large characteristic stands dominated by a principal autogenic or allogenic ecosystem engineer, which generates a modified environment that can provide habitat for other species.

In case of autogenic ecosystem engineers, these stands that are dominated by a single ecosystem engineer can provide habitat to an often diverse assemblage of smaller organisms. These may be sessile as is the autogenic engineer itself and tend to constitute a burden, such as fouling algae on seagrass blades or barnacles on mussels. On the other hand, there are mobile organisms which keep the aforementioned fouling organisms in check, i.e. grazing effects of snails on epigrowth of algae and barnacles rather than feeding on the principal ecosystem engineer. Stands that are dominated by allogenic infaunal ecosystem engineers such as, e.g., lugworms may by their joint irrigation facilitate other infauna (Volkenborn and Reise 2006) and also may accommodate inmates in their burrows (Reise 2002). In general, highly diverse benthic assemblages are expected to arise in stands dominated by a principal autogenic or allogenic ecosystem engineer which creates a complex habitat. Understanding the interplay of facilitating and inhibiting effects in a mechanistic way remains however a challenging area of research (see below).

\section{Mechanisms by which ecosystem engineers may affect biodiversity}

Due to their functional characteristics, ecosystem engineers can exert a strong influence on ecosystem properties that exceeds what may be expected based on their relative abundance alone (Hooper et al. 2005). Although conceptually this may be easily understood (Fig. 2), understanding the underlying mechanism by which these biodiversity effects occur is complex, and may involve a mix of different ecosystem characteristics: productivity, disturbance intensity, and habitat complexity.

It has been long time recognised that both productivity and stress (physical, disturbance or predation) can have a strong effect on biodiversity, for which, we summarise a simplified schematic general concept (Fig. 3). Biodiversity is the lowest in situations where productivity is maximal or where stress in the form of physical conditions, disturbance or predation is high. In areas with high productivity, the diversity is determined by competition processes. Hence, if ecosystem engineers modify the productivity, this may also explain their effect on biodiversity. A meta-analysis on this hypothesis by Wright and Jones (2004) indicated that this approach requires further testing in order to obtain a clear 


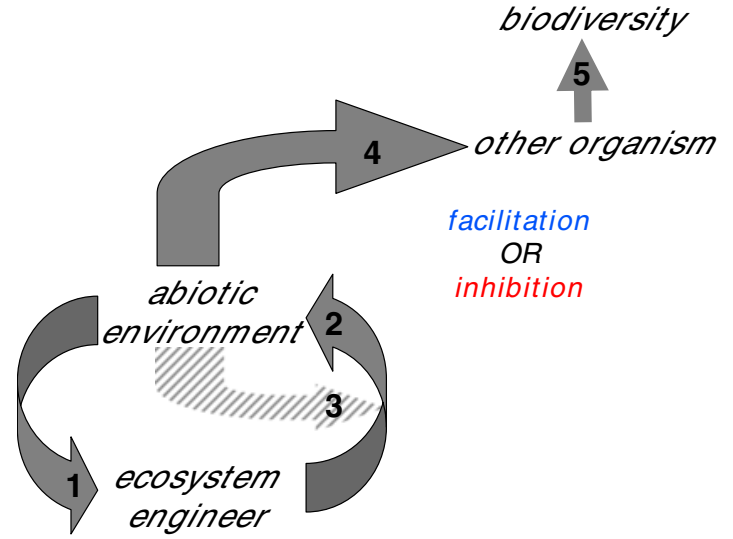

Fig. 2 Schematic representation of the general mechanism by which an ecosystem engineer may affect biodiversity. The abiotic environment affects the ability of organisms to establish (arrows 1,4). Established ecosystem engineers will modify the abiotic environment (arrow 2), with the extent of the habitat modification depending on the traits of that organism in combination with the abiotic conditions (level of environmental stress) present (arrow 3). This habitat modification will affect the ability of both the ecosystem engineer itself (arrow 1) as well as other species (arrow 4) to live in such engineered area. The latter may cause facilitation for some species and inhibition for others. The integral of the impact on all other organisms (arrow 5) describes the overall biodiversity effect of an ecosystem engineer

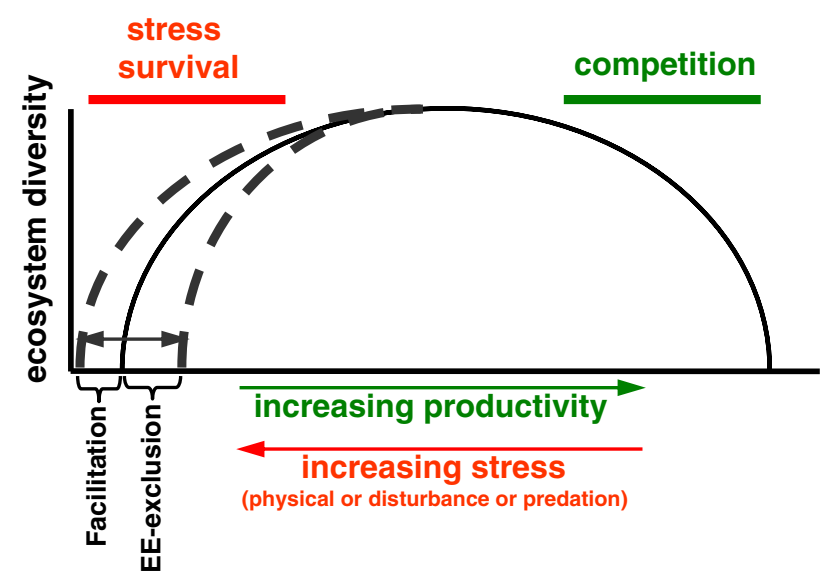

Fig. 3 Schematic representation of how community diversity may change between environments differing in stress and productivity (i.e. integrating the "predation" "intermediate disturbance" $\Leftrightarrow$ "compensatory mortality" hypotheses; after Bertness and Callaway 1994; Hacker and Gaines 1997). The dashed lines indicate how ecosystem engineers in stress dominated habitats can both enhance community diversity by facilitation processes (after Hacker and Gaines 1997) or reduce local diversity by causing negative species interactions $($ EE-exclusion $=$ ecosystem engineering-exclusion) via their modification of the environment (after van Wesenbeeck et al. 2007). These potential effects are also indicated below the $x$ axis

answer. The hydrodynamic transport of particles may make aquatic systems a suitable system to work on this type of questions (Brun et al. 2009).

In areas with high physical or disturbance stress, the diversity is kept low by the adaptations required for stress survival mechanisms. Sedimentary shores are typically governed by stress gradients related to inundation period, hydrodynamic forces and fluctuations in temperature and salinity (Fig. 4). The significance of ecosystem engineering tends to increase in stressful environments (Jones et al. 1997), and the decrease of biodiversity of aquatic organisms in up shore direction and that of terrestrial organisms in down shore direction may be mitigated by ecosystem engineering at sediment shores (Bertness 2007). There has been a growing recognition of the importance of facilitative interactions for understanding community structure and thereby the local biodiversity in stressful environments, with facilitation generally being due to ecosystem engineering species (Bruno et al. 2003). Whilst Hacker and Gaines (1997) emphasised the positive effect that facilitation by ecosystem engineers can have on community diversity in stressful environments, more recent studies indicate that ecosystem engineers can also cause direct negative species interactions via their modification of the environment (Ecosystem Engineering-exclusion or 'biomechanical warfare'; van Wesenbeeck et al. 2007). The relative balance between the role of facilitation versus EE-exclusion (i.e. space between dashed lines, Fig. 3) needs further study.

The effect of habitat complexity also fits within the concept summarised in Fig. 3, as increased habitat complexity may reduce predation stress. Autogenic ecosystem engineers often increase habitat complexity and thereby enhance biotic densities and/or diversity (Crooks 2002). A clear example of increased habitat complexity due to autogenic ecosystem engineering is the enhanced macrofaunal biodiversity in seagrass meadows (e.g. see Attrill et al. 2000; Bartholomew 2002; Bologna and Heck 1999, 2002; Edgar 1999a, b; Hovel and Lipcius 2001; Hovel et al. 2002). The effect of allogenic engineers on habitat complexity is less clear: on the one hand, disturbance generation by bioturbating allogenic engineers may destroy above-ground structures and thereby decrease habitat complexity but on the other hand the formation of burrows generates habitat complexity that may increase biodiversity. It is also noted that increased habitat complexity does not necessarily always lead to enhanced biodiversity (e.g. Castel et al. 1989), indicating that there may be other factors involved in explaining biodiversity effects of ecosystem engineers.

In addition to accounting for different mechanisms (i.e. altering productivity, physical disturbance or predation stress), understanding the effect of ecosystem engineering on biodiversity may also require accounting for scale-, species- and system-specific effects as exemplified below. (1) Ecosystem engineers can have opposite effects on different groups of organisms on different spatial scales within and directly around an engineered habitat. This has been illustrated for the mytilid mussel Musculista senhousia that 


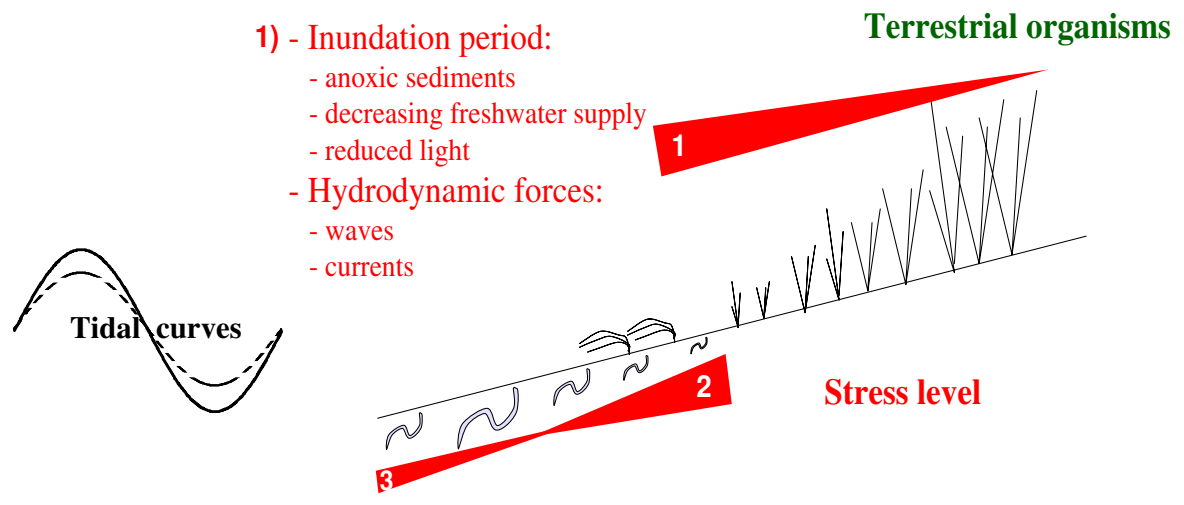

Aquatic organisms (epi and endo benthic)
Fig. 4 Schematic representation of how abiotic stresses change along the elevational gradient present at sedimentary shores for species of aquatic and terrestrial origin (see also Bertness 2007). Because of tidal curves (spring tidal amplitude schematised by solid line; neap tide by dashed line), the inundation period and frequency vary along the elevational gradient. Combined with the requirements for species with a
2) - Emersion period

- restricted feeding time / physiological active period - desiccation stress

- Fluctuations

- temperature

- Salinity

\section{3) - Hydrodynamic sediment disturbance}

more aquatic or terrestrial physiology, stresses differ along the elevational gradient (see numbers 1, 2 and 3). Habitat modification by ecosystem engineers may mitigate the stresses occurring along these gradients (e.g. by attenuating hydrodynamic energy from waves; Bruno 2000). In areas where abiotic stresses become smaller, biotic stresses will increase in importance (Bertness 2007)

\section{Biodiversity effects of epibenthic and endobenthic ecosystem engineers: the epi-endo-engineering exclusion hypothesis (hypothesis 1)}

Crooks (2002) suggested as a general pattern that autogenic ecosystem engineers often increase biodiversity by increasing habitat complexity, whereas allogenic engineers may decrease biodiversity by generating disturbances that destroy structures and habitat complexity. Other studies, however, hypothesise that in intertidal coastal zones, bioturbating allogenic ecosystem engineers may facilitate other organisms by oxygenation of otherwise anoxic sediments (see references in Reise 2002; Volkenborn et al. 2007a, b), making the picture somewhat more complex. Both these contentions are combined in Fig. 5. Basically, the first half of this hypothesis states that the biodiversity of both epibenthic and endobenthic species have an optimum curve in response to the density of epibenthic structures formed by an autogenic ecosystem engineer (Fig. 5, top). As a result of these two optimum curves, with an increasing density of epibenthic structures, the biodiversity shifts from endobenthic to epibenthic. The second half of this hypothesis states that the biodiversity of both epibenthic and endobenthic species have also an optimum curve in response to the bioturbating activity by endobenthic ecosystem engineers (Fig. 5, bottom). As a result of these two optimum curves, with an 

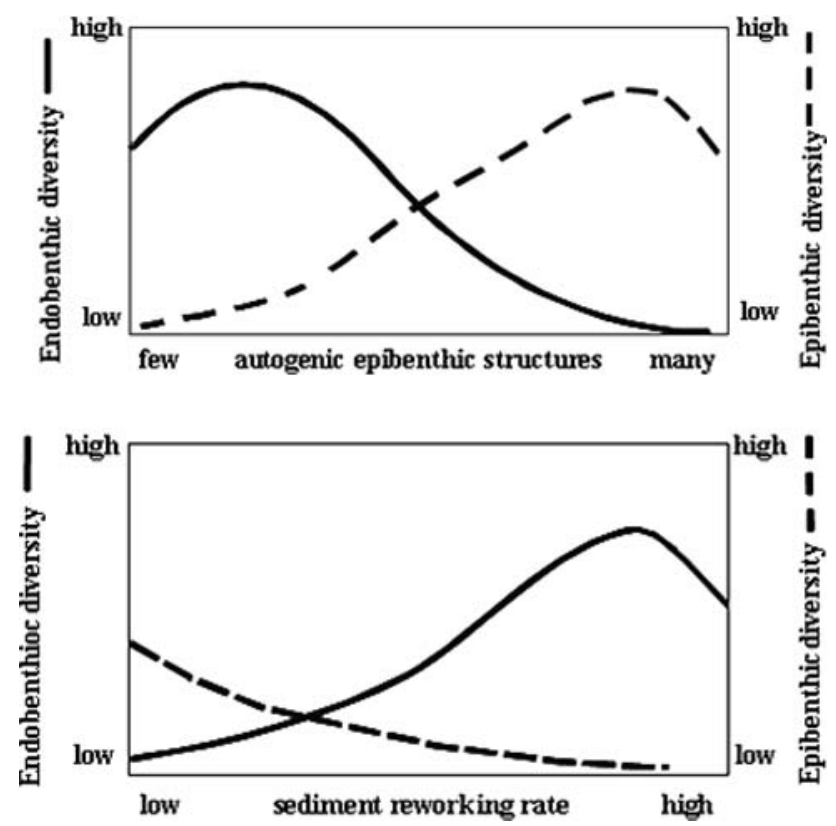

Fig. 5 Schematic representation of the epi-endo-exclusion hypothesis (hypothesis 1). The presence of epibenthic structures on soft-bottoms promotes the diversity of epibenthic organisms, whilst restricting the diversity of endobenthic ecosystem engineers (top). On the other hand, an increased sediment reworking rate due to the presence of endobenthic ecosystem engineers strongly restricts the chances for epibenthic establishment whilst endobenthic diversity is enhanced (bottom). Epibenthic and endobenthic engineers may induce alternative stable states in the same ecosystem

increasing bioturbating activity, the biodiversity shifts from epibenthic to endobenthic. It is noted that this hypothesis differs from the trophic group amensalism hypothesis (Rhoads and Young 1970) in that the present hypothesis is based on engineering groups which have very different feedbacks and thereby causing very different dynamics than trophic interactions (van Wesenbeeck et al. 2007). The attractiveness of the epi-endo-exclusion hypotheses lies in its simplicity, and thereby the ability for testing.

On a small local scale, a mixture of autogenic above- and below-ground ecosystem engineering in combination with the allogenic sediment reworking and irrigation activity will entail a high total diversity of both epibenthic and endobenthic species (e.g. Zaiko et al. 2009). However, as soon as one of these ecosystem engineers achieves dominance, it is expected that either epibenthic or endobenthic diversity is facilitated at the expense of the other and that total diversity may decline (Fig. 5). On a landscape scale, alternating patches with autogenic and allogenic ecosystem engineers are expected to produce the highest possible total diversity and species richness. It is hypothesised that high densities of both autogenic and allogenic ecosystem engineers never coincide in coastal sediments (cf. Fig. 5). Low densities, on the other hand, may coincide during succession and where harsh physical or disturbed conditions prevail.
Where epibenthic structures generated by autogenic ecosystem engineering cover most of the sediment surface, endobenthic ecosystem engineering is assumed to be excluded. Also for other endobenthos, living conditions will tend to deteriorate with increasing intensity of epibenthic ecosystem engineering (Kochmann et al. 2008; Bouma et al. 2009; Ysebaert et al. 2009). However, more complex relations arise within beds of semi-infaunal mussels (Commito et al. 2008; Buschbaum et al. 2009). It is also important to include the effects of accumulating shells (Gutiérrez et al. 2003). Primary reasons for a decrease in infaunal diversity can be anoxia in the sediment, soil compaction and limited access to the sediment surface. However, the response may not be linear and a low intensity of epibenthic engineering may actually facilitate endobenthos (Norkko et al. 2006). This effect may not show up in cohesive mud but in permeable sand. Sand may become stabilised and enriched with biodeposits. Also, individual above-ground structures may cause an advective flow ameliorating the sediment below (Hüttel and Gust 1992). Finally, endobenthic organisms may benefit from erect epibenthic structures where these offer shelter from hydrodynamic stress, mitigate low tide exposure and provide refuge against epibenthic predators such as crabs, fish and birds (Woodin 1978). However, all these facilitating effects will soon be replaced by inhibiting effects when epibenthic structures achieve a dense cover of the sediment surface.

Sediment reworking and irrigation may be the most important modes of allogenic ecosystem engineering in coastal sediments (Reise 2002). Sediment reworking destabilises the sediment and generates a dynamic sediment surface layer. This allogenic ecosystem engineering is suggested to inhibit the development of autogenic aboveground structures and keeps epibenthic biodiversity at a low level with a decrease being associated with increasing sediment reworking rate (Fig. 5, bottom). At a low density or intensity of sediment reworking, the development of epibenthic structures cannot be prevented. Where these become established, a balance between sediment reworking and epibenthic structures may allow for a relatively high combined epibenthic and endobenthic diversity. However, low sediment reworking rate does not necessarily entail epibenthic structures. These also may depend on physical stress (hydrodynamics, low tide exposure) and supply of propagules. Together, these will account for a high variability of epibenthic diversity where sediment reworking rates are low.

Endobenthos is facilitated by allogenic ecosystem engineering through burrow structures and burrow ventilation. In permeable sediment, oxygenation and modified biogeochemistry extend beyond burrows and improve living conditions for endobenthos living in the surrounding sediment. This will tend to increase endobenthic diversity. These 
facilitative effects may be partly reversed by allelochemical inhibition (Woodin et al. 1993) and destabilisation of the sediment. The latter effect will be more pronounced at a very high intensity of sediment reworking, particularly affecting small tube builders or organisms that rely on stable sediments for settling and feeding.

Autogenic ecosystem engineering may also occur below the sediment surface, i.e. roots of vascular plants, infaunal bivalves and their dead hard parts (Gutiérrez et al. 2003), and also solid worm tubes as of Lanice conchilega (e.g. Rabaut et al. 2009). Some of these below-ground structures are obviously associated to above-ground structures, but this is not necessarily the case. The presence of belowground, autogenic structures may further facilitate the development of above-ground structures and thus increase epibenthic diversity (Volkenborn et al. 2009). Autogenic structures below the surface may also have effects on endobenthic diversity. At low structural density, there may be some positive effects on endobenthos, but allelochemicals may also cause the reverse. The main effect of autogenic structures below the sediment surface will be to inhibit sediment reworking. This results in a decline of bioturbating species and thereby endobenthic diversity with increasing number of space occupation by autogenic structures. Autogenic ecosystem engineering below the sediment surface is assumed to be important in salt marshes and seagrass beds and where infaunal bivalves attain high packing. The corresponding conceptual model for endobenthic and epibenthic diversity resembles roughly the pattern shown in Fig. 5 (top) for autogenic ecosystem engineering above the surface. However, as shown for mussels by Buschbaum et al. (2009), the effects of autogenic bioengineers on biodiversity may vary among environments and the regional species pool as well as among life styles of mussels ranging from epibenthic to endobenthic modes.

\section{Effects of alien engineers on biodiversity in coastal sediments: the engineering-strength hypothesis (hypothesis 2)}

It is a widely seen paradox that new additions can make the world much more boring, if those additions are very successful and become dominant, and thereby replace a wide diversity of things that were there before. One of the clearest examples in daily society may be the invasion of fastfood and hotel chains. Adding one will increase the local restaurant/hotel diversity. However, if the formula of a chain becomes highly successful, over time several of the local restaurants and hotels will be displaced, reducing the overall local diversity. The loss of diversity is directly related to the competitive strength of the concept behind the fast-food or hotel chains. The similar paradox is likely to apply to the effect on invasive species, as invasions may cause biotic homogenisation (Olden et al. 2004). Invasive ecosystem engineers may deserve a special interest in this respect, as they do not only invade a habitat but also modify the habitat (Crooks 2002; Cuddington and Hastings 2004; Wallentinus and Nyberg 2007). Hence, invasive ecosystem engineers can exert a strong influence on ecosystem properties and biodiversity. If invasive species are ecosystem engineers, they should be regarded as high impact/high risk species. The latter is important for coastal habitats, as a wide range of alien plants and invertebrates may modify the benthic and pelagic environment through physico-chemical changes to the substrate, changes in sediment transport and water flow, modification of nutrient regime and transparency of water as well as replacement of the keystone habitat forming species (Wallentinus and Nyberg 2007). Moreover, in coastal habitats, there is a high risk for invasions due to anthropogenic activities that significantly increase the conductivity between ecosystems.

With respect to the local biodiversity effect of invasive ecosystem engineers, we pose the hypothesis that the impact depends on the engineering strength of the invasive species (Fig. 6). For the purpose of this hypothesis, we define "engineering strength" as the number of habitats that can be transformed by the invading ecosystem engineering species and define "local" as the scale of the habitats that were replaced by the habitat created by the invasive engineer. The invasion by an ecosystem engineer will create a new biogenic habitat, thereby generating habitat for biodiversity that matches these conditions (Fig. 6 left, upper dashed line). However, as the engineering species only generates one type of new habitat, the number of species that it will facilitate is limited to a maximum. (Note: for simplicity we ignore the fact that a slight increase in species number may occur in response to increasing total area covered.) A stronger ecosystem engineer can invade more habitats, thereby replacing more original habitats that were supporting another biodiversity (Fig. 6 left, lower dashed line). Hence, the stronger the ecosystem engineer, the greater the loss in biodiversity of the habitats that were transformed. As a result of these two opposing processes, the biodiversity in the invaded area will first increase and then decrease with increasing strength of the invasive ecosystem engineer (Fig. 6 right). On a larger (estuary, coastal bay) scale that also accounts for the areas that are not occupied by the invasive ecosystem engineer, the diversity does not necessarily decrease, regardless of the strength of the ecosystem engineer. The diversity effect will then of course strongly depend on the overall number of habitats that remain present in the part of the estuary or coastal bay that is regarded. But on an estuary/ecosystem scale, the diversity is always likely to increase, as complete species/habitat replacements tend to be rare in coastal ecosystems (e.g. see Wolff 2005; 


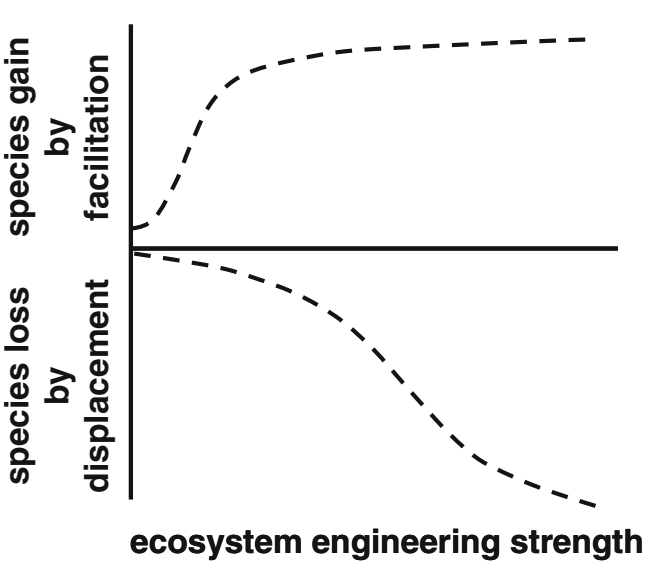

Fig. 6 Schematic representation of engineering-strength hypothesis (hypothesis 2). This hypothesis describes how local biodiversity effects of an invasive ecosystem engineer are expected to depend on the strength of the engineering species, with engineering strength defined as the number of habitats that can be invaded and transformed and local defined as the areas invaded by the engineering species. An invading engineer is likely to create a single new habitat type, thereby

Reise et al. 2006). As the invasive engineers can be either endobenthic or epibenthic species invading areas with endobenthic or epibenthic communities, the responses predicted in Fig. 6 are of course closely related to the mechanisms hypothesised in Fig. 5.

Evaluating the ecological impact of invasive species on local ecosystems may be complicated by the observation that invasive engineering species may also facilitate (endangered or rare) native species by providing novel habitat structures (Rodriguez 2006). For coastal habitats this has been exemplified for the Japanese seaweed Sargassum muticum in European waters (Buschbaum et al. 2006; Polte and Buschbaum 2008). This large alga hosts a diversity of regional taxa including fish which have been rare or absent before the invasion but once occurred in seagrass meadows which had vanished long ago. Such facilitation also applies to other alien species which may give rise to an 'invasional meltdown' (Simberloff and von Holle 1999). Near the island of Sylt in the North Sea, where the above-mentioned S. muticum is invading, it is primarily anchored by clusters of Pacific oysters and American slipper limpets (Reise and Buschbaum, pers. observation). Without these other aliens, S. muticum would have been more limited in its spread. For a proper method to assess the impact of invasive ecosystem engineering species, we refer to Olenin et al. (2007), who integrated criteria for habitat alteration, habitat fragmentation and habitat loss.

The simplest way to predict the impact that a specific species may have upon invasion of a new area seems to be evaluating the effect of that species on the habitats it currently occupies (either native or invaded). Such approach is

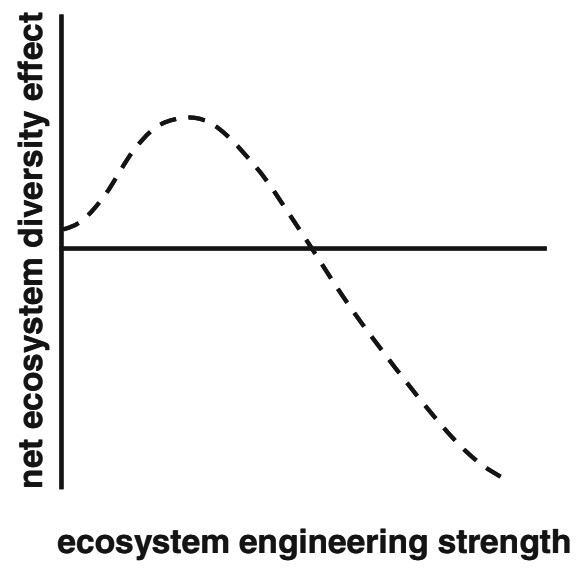

putting a maximum on the species gain. The stronger the ecosystem engineer, the more existing habitat types with their communities it will displace. As a result, a stronger ecosystem engineer is likely to cause a net decrease of biodiversity when regarded at the local scale. On a larger scale, also accounting for the areas that are not occupied by the invasive ecosystem engineer, diversity effects can be very different and will strongly depend on the chosen scale

however likely to be too simple as the impact of an invasive species will strongly depend on the conditions under which they occur, as exemplified for mussels and oysters (Kochmann et al. 2008; Buschbaum et al. 2009; Smaal et al. 2009; Zaiko et al. 2009). Moreover, it is difficult to predict the invasiveness of a specific area based on observations from another area, as the chances for invasive species depend both on a mixture of competitive and positive interactions (Bulleri et al. 2008) and other ecological factors such as propagule supply and the absence of predators, parasites and diseases (e.g. see Engelkes et al. 2008; Levine 2000; Reinhart et al. 2003; Theoharides and Dukes 2007). The strength of the residing ecosystem engineers will also strongly determine the chances of other engineering species to invade and take over their habitat as may be seen from the negative species interactions that may occur via habitat modification (Ecosystem Engineering-exclusion or 'biomechanical warfare'; van Wesenbeeck et al. 2007). Thus, predicting the effect of an invasive engineering species on forehand is difficult, but experience learns most invasive engineers have high impacts (Crooks 2002).

There remains one last issue to be considered with respect to the impact of invasive species, which is difficult to translate in numbers. Although we may make an assessment of the impact of an ecosystem engineer using the approach introduced by Olenin et al. (2007), the visual effect on the appearance of the landscape may be very large. For example, a relative small reef, e.g. Japanese oysters on a bare tidal flat, may cause a visual impact that greatly exceeds their quantitative impact on the ecosystem (cf. the visual 'pollution' of identical fast-food restaurants all 

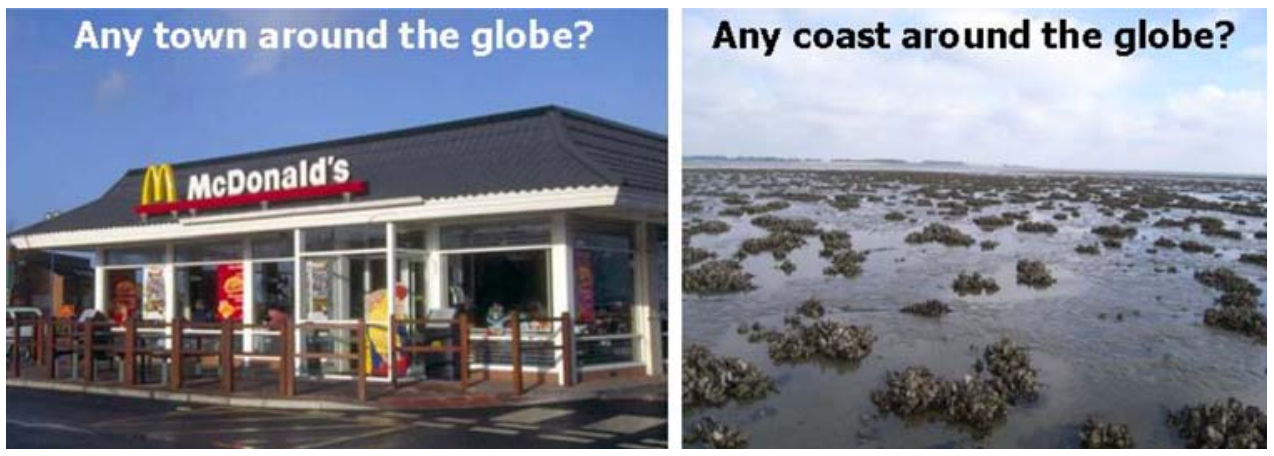

Fig. 7 The visual effect of strong invasive ecosystem engineers may qualitatively greatly exceed the quantitative biodiversity influence, by creating a strong resemblance in a heterogeneous environment. Will

around the world; Fig. 7). Such esthetical factors are also important to take into account when evaluating the biotic homogenisation effect of invasive species.

\section{Human impacts on ecosystem engineers in coastal sediments: threats and opportunities}

An in-depth understanding of the impacts of biodiversity loss (Worm et al. 2006) and reduction of ecosystem size (Barbier et al. 2008) on ecosystem services is essential to the well being of mankind. Although it has been recognised that coastal ecosystems dominated by autogenic epibenthic engineers belong to the most valuable ecosystems among the world (Costanza et al. 1997), they remain threatened and declining (Lotze et al. 2006; Orth et al. 2006). Hence there is an urgent need to understand in depth how biodiversity and ecosystem functioning in coastal ecosystems is affected by the presence (and the loss) of such habitat building ecosystem engineers. The presented conceptual hypotheses may help making predictions. For example, autogenic ecosystem engineers are generally more vulnerable to bottom trawling or other physical habitat disturbances than allogenic ecosystem engineers, for which mixed responses are observed (Thrush and Dayton 2002). This is because the former reside mostly on the sediment surface, whilst the latter are usually deeply buried in the sediment. When physical disturbances by, e.g., bottom trawling increase in intensity and scale (i.e. shift towards left side $x$ axis Fig. 3) causing more and more of the epibenthic structures become destroyed, then total diversity will be confined to endobenthic species alone (cf. Fig. 5). This may also be seen as an example of the effect of a strong invasive engineer (humans) that transform a multitude of habitats into a single type, thereby reducing overall biodiversity (cf. Fig. 6). Hence it is likely that bottom trawling causes a reduction of the overall number of habitat types, thereby causing the overall diversity to decrease. ecosystems follow economical systems, causing visual similarity all over the globe? McDonald's pictures obtained from http://www.freefoto.com/preview/04-05-11?ffid=04-05-11\&k=McDonalds

Although several commercially exploited marine invertebrate and vertebrate species are well recognised for being ecosystem engineers, the consequences of their removal from ecosystems remain largely unknown beyond the single species or population level (Coleman and Williams 2002). However, (over)exploitation of engineering species is likely to have consequences that extend beyond their own decline and strongly affect the rest of the ecosystem. For example, harvesting of oysters and the consequent destruction of oyster reefs resulted in multiple ecosystem effects (Reise 1982; Lenihan and Peterson 1998). Recent (exclusion) experiments also demonstrated the role of endobenthic, allogenic ecosystem engineers on ecosystem function (Thrush et al. 2006; Volkenborn et al. 2007b; Montserrat et al. 2008). These studies provide insight into the effects of (human-induced) losses of ecosystem engineers on ecosystem functioning and performance, which are of great relevance for the conservation and management of these systems.

The ecosystem engineer concept offers promising opportunities for restoration ecology (Crain and Bertness 2006), but has yet to be formally and explicitly applied. Identifying and managing probable engineering species and responsive ecosystems should be a key priority for conservation. The latter will necessitate a shift to a process-based understanding of the functioning of whole systems, which is a large and important step toward ecosystem-based management (Byers et al. 2008). Posing testable generalising hypotheses on the effect of ecosystem engineers is an important step in obtaining a broadly applicable processbased understanding.

Acknowledgments We greatly acknowledge the European network of excellence "MarBEF" for funding the research group "The role of native and/or invasive ecosystem engineers in explaining biodiversity". We like to thank the following European partners for their inputs in the discussions at the various MarBEF workshops: NIOO: P. Herman, B. van Wesenbeeck, E. Cacabellos, F. Brun, F. Montserrat, L. van Duren; UIB-IMEDEA: I. Hendriks, S. Deudero; $A W I$ : 
C. Buschbaum, J. Kochmann, N. Volkenborn, A. Schanz; BI-USD: E. Kristensen; IMARES: A. Smaal, K. Troost, P. Kamermanns; KU-CORPI: A. Zaiko, M. Bučas, D. Daunys, A. Šiaulys; FIMR: A. Norkko. We especially thank C. Heip, H. Hummel, P. van Avesaath, I. Hendriks and R. Aspen for their support from the MarBEF organisation. P. Herman, C. Buschbaum and N. Volkenborn are acknowledged for critical comments on earlier versions of the MS. S. Olenin was partly supported by the Lithuanian State Science and Study Foundation Project BINLIT "Biological invasions in Lithuanian ecosystems under the climate change: causes, impacts and projections". This publication is contribution number MPS-09005 of MarBEF and publication 4483 of the Netherlands Institute of Ecology (NIOO-KNAW).

Open Access This article is distributed under the terms of the Creative Commons Attribution Noncommercial License which permits any noncommercial use, distribution, and reproduction in any medium, provided the original author(s) and source are credited.

\section{References}

Ackerman JD, Okubo A (1993) Reduced mixing in a marine macrophyte canopy. Funct Ecol 7:305-309

Atkinson RJA, Taylor AC (2005) Aspects of the physiology, biology and ecology of thalassinidean shrimps in relation to their burrow environment. Oceanogr Mar Biol Annu Rev 43:173210

Attrill MJ, Strong JA, Rowden AA (2000) Are macroinvertebrate communities influenced by seagrass structural complexity? Ecography 23:114-121

Barbier EB, Koch EW, Silliman BR, Hacker SD, Wolanski E, Primavera J, Granek EF, Polasky S, Aswani S, Cramer LA, Stoms DM, Kennedy CJ, Bael D, Kappel CV, Perillo GME, Reed DJ (2008) Coastal ecosystem-based management with nonlinear ecological functions and values. Science 319:321

Bartholomew A (2002) Faunal colonization of artificial seagrass plots: the importance of surface area versus space size relative to body size. Estuaries 25:1045-1052

Bertness MD (2007) Atlantic shorelines: natural history and ecology. Princeton University Press, Princeton, $431 \mathrm{pp}$

Bertness MD, Callaway R (1994) Positive interactions in communities. Trends Ecol Evol 9:191-193

Bologna PAX, Heck KL (1999) Macrofaunal associations with seagrass epiphytes-relative importance of trophic and structural characteristics. J Exp Mar Biol Ecol 242:21-39

Bologna PAX, Heck KL (2002) Impact of habitat edges on density and secondary production of seagrass-associated fauna. Estuaries 25:1033-1044

Bouma TJ, De Vries MB, Low E, Peralta G, Tánczos IC, van de Koppel J, Herman PMJ (2005) Trade-offs related to ecosystem-engineering: a case study on stiffness of emerging macrophytes. Ecology 86:2187-2199

Bouma TJ, Friedrichs M, van Wesenbeeck BK, Temmerman S, Graf G, Herman PMJ (2009) Density-dependent linkage of scaledependent feedbacks: a flume study on the intertidal macrophyte Spartina anglica. OIKOS (in press)

Braun-Blanquet J (1928) Pflanzensoziologie. Grundzüge der Vegetationskunde. Biologische Studienbücher 7. Springer, Berlin

Brun FG, van Zetten E, Cacabelos E, Bouma TJ (2009) Role of two contrasting ecosystem engineers (Zostera noltii and Cymodocea nodosa) in the food intake rate of Cerastoderma edule. Helgol Mar Res. doi:10.1007/s10152-008-0134-7

Bruno JF (2000) Facilitation of cobble beach plant communities through habitat modification by Spartina alterniflora. Ecology 81:1179-1192
Bruno JF, Stachowicz JJ, Bertness MD (2003) Inclusion of facilitation into ecological theory. Trends Ecol Evol 18:119-125

Bulleri F, Bruno JF, Benedetti-Cecchi L (2008) Beyond competition: incorporating positive interactions between species to predict ecosystem invisibility. PLoS Biol 6(6):e162. doi:10.1371/journal. pbio.0060162

Buschbaum C, Chapman AS, Saier B (2006) How an introduced seaweed can affect epibiota diversity in different coastal systems. Mar Biol 148:743-754

Buschbaum C, Dittmann S, Hong JS, Hwang IS, Strasser M, Thiel M, Valdivia N, Yoon SP, Reise K (2009) Mytilid mussels: global habitat engineers in coastal sediments. Helgol Mar Res. doi:10.1007/s10152-008-0139-2

Byers JE, Cuddington K, Jones CG, Talley TS, Hastings A, Lambrinos JG, Crooks JA, Wilson WG (2008) Using ecosystem engineers to restore ecological systems. Trends Ecol Evol 219:493-500

Cadée GC (2001) Sediment dynamics by bioturbating organisms. In: Reise K (ed) Ecological comparisons of sedimentary shores. Springer, Berlin, pp 127-236

Castel J, Labourg PJ, Escaravage V, Auby I, Garcia ME (1989) Influence of seagrass beds and oyster parks on the abundance and biomass patterns of meiobenthos and macrobenthos in tidal flats. Estuar Coast Shelf Sci 28:71-85

Castellanos EM, Figueroa ME, Davy AJ (1994) Nucleation and facilitation in saltmarsh succession: interactions between Spartina maritima and Arthrocnemum perenne. J Ecol 82:239-248

Coleman FC, Williams SL (2002) Overexploiting marine ecosystem engineers: potential consequences for biodiversity. Trends Ecol Evol 17:40-44

Commito JA, Como S, Grupe BM, Dow WE (2008) Species diversity in the soft-bottom intertidal zone: biogenic structure, sediment, and macrofauna across mussel bed spatial scales. J Exp Mar Biol Ecol 366:70-81

Costanza R, dArge R, deGroot R, Farber S, Grasso M, Hannon B, Limburg K, Naeem S, ONeill RV, Paruelo J, Raskin RG, Sutton P, van den Belt M (1997) The value of the world's ecosystem services and natural capital. Nature 387:253-260

Crain CM, Bertness MD (2006) Ecosystem engineering across environmental gradients: implications for conservation and management. Bioscience 56:211-218

Crooks JA (1998) Habitat alteration and community-level effects of an exotic mussel, Musculista senhousia. Mar Ecol Prog Ser 162:137-152

Crooks JA (2001) Assessing invader effects within changing ecosystems: historical and experimental perspective on the role of the exotic mussel in an urban lagoon. Biol Invasions 3:23-36

Crooks JA (2002) Characterizing ecosystem-level consequences of biological invasions: the role of ecosystem engineers. OIKOS 97:153-166

Crooks JA, Khim HS (1999) Architectural vs. biological effects of a habitat-altering, exotic mussel, Musculista senhousia. J Exp Mar Biol Ecol 240:53-75

Cuddington K, Hastings A (2004) Invasive engineers. Ecol Model $178: 335-347$

Edgar GJ (1999a) Experimental analysis of structural versus trophic importance of seagrass beds. I. Effects on macrofaunal and meiofaunal invertebrates. Vie Et Milieu-Life Environ 49:239-248

Edgar GJ (1999b) Experimental analysis of structural versus trophic importance of seagrass beds. II. Effects on fishes, decapods and cephalopods. Vie Et Milieu-Life Environ 49:249-260

Engelkes T, Morrien E, Verhoeven KJF, Bezemer TM, Biere A, Harvey JA, McIntyre LM, Tamis WLM, van der Putten WH (2008) Successful range-expanding plants experience less above-ground and below-ground enemy impact. Nature 456:946-948

Fréchette M, Bourget E (1985) Energy flow between the pelagic and benthic zones: factors controlling particulate organic matter 
available to an intertidal mussel bed. Can J Fish Aquat Sci 42:1158-1165

Gacia E, Duarte CM, Marba N, Terrados J, Kennedy H, Fortes MD, Tri NH (2003) Sediment deposition and production in SE-Asia seagrass meadows. Estuar Coast Mar Sci 56:909-919

Gutiérrez JL, Jones CG, Strayer DL, Iribarne OO (2003) Mollusks as ecosystem engineers: the role of shell production in aquatic habitats. OIKOS 101:79-90

Hacker SD, Gaines SD (1997) Some implications of direct positive interactions for community species diversity. Ecology 78:19902003

Hemminga MA, van Soelen J, Maas YEM (1998) Biomass production in pioneer Spartina anglica patches: evidence for the importance of seston particle deposition. Estuar Coast Shelf Sci 47:797-805

Hooper DU, Chapin FS, Ewel JJ, Hector A, Inchausti P, Lavorel S, Lawton JH, Lodge DM, Loreau M, Naeem S, Schmid B, Setala H, Symstad AJ, Vandermeer J, Wardle DA (2005) Effects of biodiversity on ecosystem functioning: a consensus of current knowledge. Ecol Monogr 75:3-35

Hovel KA, Lipcius RN (2001) Habitat fragmentation in a seagrass landscape: patch size and complexity control blue crab survival. Ecology 82:1814-1829

Hovel KA, Fonseca MS, Myer DL, Kenworthy WJ, Whitfield PE (2002) Effects of seagrass landscape structure, structural complexity and hydrodynamic regime on macrofaunal densities in North Carolina seagrass beds. Mar Ecol Prog Ser 243:11-24

Hüttel M, Gust G (1992) Impact of bioroughness on interfacial solute exchange in permeable sediments. Mar Ecol Prog Ser 89:253267

Jones CG, Lawton JH, Shachak M (1994) Organisms as ecosystem engineers. OIKOS 69:373-386

Jones CG, Lawton JH, Shachak M (1997) Positive and negative effects of organisms as physical ecosystem engineers. Ecology 78:19461957

Koch EM (2001) Beyond light: physical, geological, and geochemical parameters as possible submersed aquatic vegetation habitat requirements. Estuaries 24:1-17

Koch EW, Gust G (1999) Water flow in tide- and wave-dominated beds of the seagrass Thalassia testudinum. Mar Ecol Prog Ser 184:63-72

Koch EW, Ackerman JD, Verduin J, Van Keulen M (2006) Fluid dynamics in seagrass ecology-from molecules to ecosystems. In: Larkum AWD, Orth RJ, Duarte CM (eds) Seagrass biology, ecology and conservation. Springer, Dordrecht, pp 193-225

Kochmann J, Buschbaum C, Volkenborn N, Reise K (2008) Shift from native mussels to alien oysters: differential effects of ecosystem engineers. J Exp Mar Biol Ecol 364:1-10

Kristensen K (2008) Mangrove crabs as ecosystem engineers: with emphasis on sediment processes. J Sea Res 59:30-43

Lenihan HS, Peterson CH (1998) How habitat degradation through fishery disturbance enhances impacts of hypoxia on oyster reefs. Ecol Appl 8:128-140

Levine JM (2000) Species diversity and biological invasions: relating local processes to community pattern. Science 288:852-854

Lotze HK, Lenihan HS, Bourque BJ, Bradbury RH, Cooke RG, Kay MC, Kidwell SM, Kirby MX, Peterson CH, Jackson JBC (2006) Depletion, degradation, and recovery potential of estuaries and coastal seas. Science 312:1806-1809

Meysman FJR, Middelburg JJ, Heip CHR (2006) Bioturbation: a fresh look at Darwin's last idea. Trends Ecol Evol 21:688-695

Montserrat F, Van Colen C, Degraer S, Ysebaert T, Herman PMJ (2008) Ecosystem engineering effects of a benthic community: a defaunation study. Mar Ecol Prog Ser 372:43-59

Norkko A, Hewitt JE, Thrush SF, Funnel GA (2006) Conditional outcomes of facilitation by a habitat-modifying subtidal bivalve. Ecology 87:226-234
Olden JD, Poff NL, Douglas MR, Douglas ME, Fausch KD (2004) Ecological and evolutionary consequences of biotic homogenization. Trends Ecol Evol 19:18-24

Olenin S, Minchin D, Daunys D (2007) Assessment of biopollution in aquatic ecosystems. Mar Pol Bul 55:379-394

Orth RJ, Carruthers TJB, Dennison WC, Duarte CM, Fourqurean JW, Heck KL, Hughes AR, Kendrick GA, Kenworthy WJ, Olyarnik S, Short FT, Waycott M, Williams SL (2006) A global crisis for seagrass ecosystems. Bioscience 56:987-996

Peralta G, van Duren LA, Morris EP, Bouma TJ (2008) Consequences of shoot density and stiffness for ecosystem engineering by benthic macrophytes in flow dominated areas: a hydrodynamic flume study. Mar Ecol Prog Ser 368:103-115

Peterson CH, Luettich RA, Micheli F, Skilleter GA (2004) Attenuation of water flow inside seagrass canopies of differing structure. Mar Ecol Prog Ser 268:81-92

Polte P, Buschbaum C (2008) Native pipefish Entelurus aequoreus are promoted by the introduced seaweed Sargassum muticum in the northern Wadden Sea. Aquat Biol 3:11-18

Rabaut M, Vincx M, Degraer S (2009) Do Lanice conchilega (sandmason) aggregations classify as reefs? Quantifying habitat modifying effects. Helgol Mar Res. doi:10.1007/s 10152-008-0137-4

Reimers NF, Yablokov AV (1982) Glossary on nature management terms. Nauka Press, Moscow, 144 pp (in Russian)

Reinhart KO, Packer A, van der Putten WH, Clay K (2003) Plant-soil biota interactions and spatial distribution of black cherry in its native and invasive ranges. Ecol Lett 6:1046-1050

Reise K (1982) Long-term changes in the macrobenthic invertebrate fauna of the Wadden Sea: are polychaetes about to take over? Neth J Sea Res 16:29-36

Reise K (2002) Sediment mediated species interactions in coastal waters. J Sea Res 48:127-141

Reise K, Simon M, Herre E (2001) Density-dependent recruitment after winter disturbance on tidal flats by the lugworm Arenicola marina. Helgol Mar Res 55:161-165

Reise K, Olenin S, Thieltges DW (2006) Are aliens threatening European aquatic coastal ecosystems? Helgol Mar Res 60:77-83

Reusch TBH, Williams SL (1998) Variable responses of native eelgrass Zostera marina to a non-indigenous bivalve Musculista senhousia. Oecologia 113:428-441

Rhoads DC (1974) Organism-sediment relations on the muddy sea floor. Oceanogr Mar Biol Annu Rev 12:223-300

Rhoads DC, Young DK (1970) Influence of deposit-feeding organisms on sediment stability and community trophic structure. J Mar Res 28:150

Rodriguez LF (2006) Can invasive species facilitate native species? Evidence of how, when, and why these impacts occur. Biol Invasions 8:927-939

Simberloff D, von Holle B (1999) Positive interactions of nonindigenous species: invasional meltdown? Biol Invasions 1:21-32

Smaal AC, Kater BJ, Wijsman J (2009) Introduction, establishment and expansion of the Pacific oyster Crassostrea gigas in the Oosterschelde (SW Netherlands). Helgol Mar Res. doi:10.1007/ s10152-008-0138-3

Theoharides KA, Dukes JS (2007) Plant invasion across space and time: factors affecting nonindigenous species success during four stages of invasion. New Phytol 176:256-273

Thrush SF, Dayton PK (2002) Disturbance to marine benthic habitats by trawling and dredging: implications for marine biodiversity. Annu Rev Ecol Systematics 33:449-473

Thrush SF, Hewitt JE, Gibbs M, Lundquist C, Norkko A (2006) Functional role of large organisms in intertidal communities: community effects and ecosystem functioning. Ecosystems 9:1029-1040

van der Heide T, van Nes EH, Geerling GW, Smolders AJP, Bouma TJ, van Katwijk MM (2007) Positive feedbacks in seagrass ecosystems - theoretical and management implications. Ecosystems 10:1311-1322 
van Hulzen JB, van Soelen J, Bouma TB (2007) Morphological variation and habitat modification are strongly correlated for the autogenic ecosystem engineer Spartina anglica (common cordgrass). Estuar Coast 30:3-11

van Wesenbeeck BK, van de Koppel J, Herman PMJ, Bakker JP, Bouma TJ (2007) Biomechanical warfare in ecology; negative interactions between species by habitat modification. OIKOS 116:742-750

van Wesenbeeck BK, van de Koppel J, Herman PMJ, Bertness MD, van der Wal D, Bakker JP, Bouma TJ (2008) Potential for sudden shifts in transient systems: distinguishing between local and landscape-scale processes. Ecosystems 11:1133-1141

Volkenborn N, Reise K (2006) Lugworm exclusion experiment: responses by deposit feeding worms to biogenic habitat transformations. J Exp Mar Biol Ecol 330:169-179

Volkenborn N, Hedtkamp SIC, van Beusekom JEE, Reise K (2007a) Effects of bioturbation and bioirrigation by lugworms (Arenicola marina) on physical and chemical sediment properties and implications for intertidal habitat succession. Estuar Coast Shelf Sci 74:331-343

Volkenborn N, Polerecky L, Hedtkamp SIC, van Beusekom JEE, de Beer D (2007b) Bioturbation and bioirrigation extend the open exchange regions in permeable sediments. Limnol Oceanogr 52:1898-1909

Volkenborn N, Robertson D, Reise K (2009) Sediment destabilizing and stabilizing bio-engineers on tidal flats: cascading effects of experimental exclusion. Helgol Mar Res. doi:10.1007/s10152008-0140-9

Wallentinus I, Nyberg CD (2007) Introduced marine organisms as habitat modifiers. Mar Poll Bull 55:323-332

Widdows J, Brisley M (2002) Impact of biotic and abiotic processes on sediment dynamics and the consequences to the structure and functioning of the intertidal zone. J Sea Res 48:143-156

Widdows J, Brinsley MD, Salkeld PN, Elliott M (1998) Use of annular flumes to determine the influence of current velocity and bivalves on material flux at the sediment-water interface. Estuaries 21:552-559

Widdows J, Lucas JS, Brinsley MD, Salkeld PN, Staff FJ (2002) Investigation of the effects of current velocity on mussel feeding and mussel bed stability using an annular flume. Helgol Mar Res $56: 3-12$

Wolff WJ (2005) The exploitation of living resources in the Dutch Wadden Sea: a historical overview. Helgol Mar Res 59:31-38

Woodin SA (1978) Refuges, disturbance, and community structure: a marine soft-bottom example. Ecology 59:274-284

Woodin SA, Marinelli RL, Lincoln DE (1993) Allelochemical inhibition of recruitment in a sedentary assemblage. J Chem Ecol 19:517-530

Worm B, Barbier EB, Beaumont N, Duffy JE, Folke C, Halpern BS, Jackson JBC, Lotze HK, Micheli F, Palumbi SR, Sala E, Selkoe KA, Stachowicz JJ, Watson R (2006) Impacts of biodiversity loss on ocean ecosystem services. Science 314:787-790

Wright JP, Jones CG (2004) Predicting effects of ecosystem engineers on patch-scale species richness from primary productivity. Ecology 85:2071-2081

Wright JP, Jones CG (2006) The concept of organisms as ecosystem engineers ten years on: progress, limitations, and challenges. Bioscience 56:203-209

Wright JP, Jones CG, Boeken B, Shachak M (2006) Predictability of ecosystem engineering effects on species richness across environmental variability and spatial scales. J Ecol 94:815-824

Ysebaert T, Hart M, Herman PMJ (2009) Impacts of bottom and suspended cultures of mussels Mytilus spp. on the surrounding sedimentary environment and macrobenthic biodiversity. Helgol Mar Res. doi:10.1007/s10152-008-0136-5

Zaiko A, Daunys D, Olenin S (2009) Habitat engineering by the invasive zebra mussel Dreissena polymorpha (Pallas) in a boreal coastal lagoon: impact on biodiversity. Helgol Mar Res. doi:10.1007/s10152-008-0135-6 